\title{
Modern Biotechnology and New Food Varieties
}

\author{
Fabien Nsanzabera ${ }^{1}$, Liu Song ${ }^{1}$, Guocheng Du ${ }^{1}$, Byong H. Lee $e^{1,2, *}$ \\ ${ }^{1}$ Laboratory of Biosystem and Bioprocessing Engineering, School of Biotechnology, Jiangnan University, Wuxi, Jiangsu Province, P. R \\ China \\ ${ }^{2}$ Department of Food Science and Biotechnology, Kangwon National University, South Korea, Department of Food Science and Agricultural \\ Chemistry, McGill University, Ste-Anne-de-Bellevue, QC, Canada
}

\section{Email address:}

nsanzabera@gmail.com (F. Nsanzabera), liusong@jiangnan.edu.cn (Liu Song), gcdu@jiangnan.edu.cn (Guocheng Du), byonghlee@yahoo.ca (Byong H. Lee)

${ }^{*}$ Corresponding author

\section{To cite this article:}

Fabien Nsanzabera, Liu Song, Guocheng Du, Byong H. Lee. Modern Biotechnology and New Food Varieties. Advances in Biochemistry. Vol. 4, No. 3, 2016, pp. 26-33. doi: 10.11648/j.ab.20160403.12

Received: April 24, 2016; Accepted: May 13, 2016; Published: May 25, 2016

\begin{abstract}
The world population is predicted to reach 9.5 billion by 2050 . This will demand powerful techniques in agricultural production. Transgenic technology can be used in both crops and animals through improved crop production, milk production and composition, improved meat production, increased disease resistance and prolificacy. To create a stable transgenic organism, foreign gene is transferred using specific methods suitable for a particular species, that include DNA microinjection, sperm-mediated DNA transfer and somatic cell nuclear transfer for transgenic animals production and Agrobacterium-mediated, microprojectile bombardment, direct DNA transfer to protoplasts for plant transformation. However, the safety of transgenic food and derivatives in the markets has to be verified for the presence and the amount of genetic modification varieties. This review addresses up to date progress from the genetically modified food industry.
\end{abstract}

Keywords: Gene Transfer, GM Food, Plant Transformation, Safety Issue, Transgenic Organism

\section{Introduction}

Biotechnology is the application of scientific techniques to modify plants, animals, and microorganisms to improve their value. Since time immemorial, man has been using green biotechnology to improve the quality, quantity and production outcomes of nutrients. The use of this green biotechnology can offer several potential advantages for food security, which include increase of food production, reduction of agricultural water use, decrease of greenhouse gas emission, decrease of insecticide and herbicide use, improvement of nutritional value, enhancing crop adaptation and reduction of soil physical damage [1-4]. Through cross breeding techniques, man used to change and improve the quality of food products of the selected plants and animals that harbor the most desirable traits for food production and breeding for next generation. These traits should present a high yield, be easy to harvest and be non-toxic $[5,6]$. The most recent application of green biotechnology is genetic modification (GM), also referred to as gene technology, genetic engineering, genetic manipulation or recombinant DNA technology. This technology involves the insertion of a gene from a foreign source such as yeasts, viruses, bacteria, animals or plants into typically unrelated species [7]. The plants and animals, in which the genes of interest are added to their genomic DNA, are described as genetically modified organisms (GMO). The plants and animals start to express the proteins of the inserted genes while they grow and develop, which leads to several changes in the organism; such as structure of molecules, anatomy, biochemistry, physiology and morphology thus resulting in the creation of a new living entity not found in nature $[6,8]$.

The world population has increased at a slow, steady pace which demands increasing the supply of food to meet future needs. This will require increasing crop yields and cropping intensity. It is therefore imperative to invest in agricultural research to increase the yield potentials of specific food crops as well as fish and livestock production, which has forced farmers from different countries, such as; Argentine, Mexico, USA, Canada and China to directly adopt the new genetically 
modified (GM) crop varieties as they become available. The application of GM technology showed several benefits in different domain like agriculture and food industries. The GM technology increases farming productivity and reduces chemical use (e.g. using pesticide-inherent crops and herbicide-tolerant crops), and lower the production cost which subsequently reduces price. Therefore adoption of GM technology could be regarded as a pro-poor strategy [9-13]. The 2013 report has estimated that 18 million farmers from 27 different countries planted 175.2 million hectares of transgenic crops (Figure 1) [14, 15].

Herein study, we addressed the vital role of transgenic food to the hungry world, the most commonly used methods for the creation of GM food, the labeling regulations and detection methods for GM food and products, and the safety issue of GM food and products.

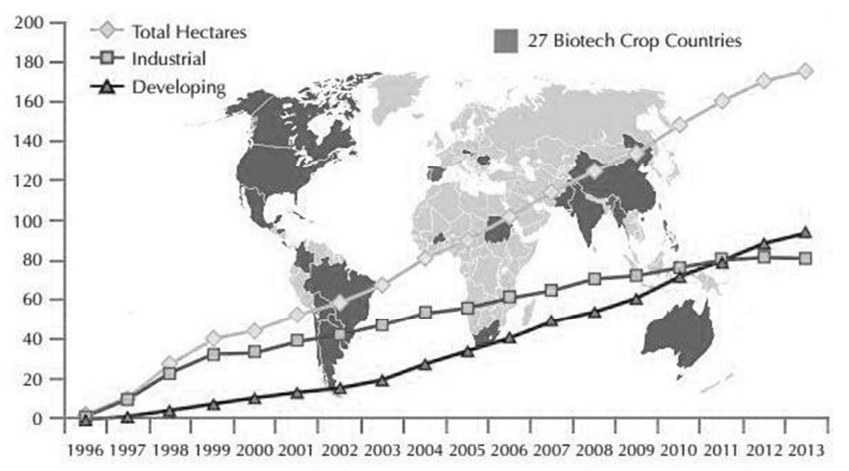

Source: [14]

Figure 1. Global area of biotech crops from 1996 to 2013 (million hectares).

\section{GM foods and Poverty Alleviation}

The Food and Agriculture Organization (FAO) estimated that about 870 million people was chronically undernourished during $2010-2012$, that is $12.5 \%$ of global population or one in eight people, with most of these people live in developing countries. This indicates that the first target of the Millennium Development Goal (MDG) which is to halving the world hunger by 2015 has faced certain limitations, among which, the rapid increase of global population and climate change $[16,17]$. The world population is continually increasing from 7.2 billion in 2000 to a predicted 9.5 billion in $2050[18,19]$ and a doubling of the global demand for food will occur between 2000 and 2050 as reported by FAO. This increased demand will require competent agriculture techniques with a fast pace to double the current food production $[20,21]$. In the coming years, food and agricultural production techniques should also be improved to meet other anthropomorphic changes, such as an increasing international competition, loss of biodiversity, globalization, shifts to increased meat consumption in developing countries, land availability and degradation, climate change, and rising consumer demands for improved food quality, safety, food insecurity and health enhancement. This demands new technical knowledge that contributes reliable methods for improving quality, productivity, and environmental sustainability. Biotechnology has introduced a new area by supplying efficient and cost-effective means to produce a large number of improved and desirable products and tools. This includes the enhancement of quality and quantity of food, feed, fiber, and biofuel production; hence, changing the heading date of crops, reducing the dependency of agriculture on chemicals and fossil fuels, diminishing over-cultivation and erosion and lower the cost of raw materials, and enhancing the photosynthetic efficiency where currently efforts are going on to convert $\mathrm{C} 3$ plants into $\mathrm{C} 4$ plants, all in an environmentally friendly way [20, 22].

All over the world, farmers have been helped by green biotechnology to enhance their productivity. Bt cotton varieties in about 2.1 million hectares were grown in 2002 by around five million farmers. During this time, one kilogram of $\mathrm{Bt}$ cotton cost $28 \%$ less than non-Bt varieties. This was attributed to a reduction of pesticide application by $59-80 \%$ compared to conventional cotton (assessed in 3 years of use) [23]. Rice and maize are the main food and food derived products resources; 4 billion USD annual benefits were generated from $\mathrm{Bt}$ rice which showed the potential to increase yields up to $8 \%$ and decrease pesticide use by $80 \%$ equivalent to $17 \mathrm{~kg} / \mathrm{ha}$ [24]. Thus, green biotechnology has indeed proved its potential to counteract the world's hunger. Until 2003, U.S. Department of Agriculture had already approved twelve transgenic crops: corn, tomato, soybean, cotton, potato, canola, squash, beets, papaya, rice, flax, and chicory for commercial production. These transgenic crops have contributed to biodiversity, enhance crop quality and yield, and improve the environmental quality by reducing uses of herbicides and pesticides $[6,15]$.

\section{Plant Transformation}

Plant transformation was started in 1980s after many researches which demonstrated that Agrobacterium tumefaciens which causes crown gall disease could be used to introduce interested DNA fragments into plant cells [25, 26]. Plant transformation is defined as the introduction and integration of foreign DNA fragment in plant cells which leads to generation of transgenic plants. This process can lead to transient or stable expression of the introduced DNA. Transient expression lasts for a few days, the transformed DNA is not integrated into nucleus of the host genome; therefore the incoming DNA fragment will be degraded through mitosis [26]. A stable transformation occurs when it is needed to maintain the introduced DNA in the genome of the cell and its daughter cells [26, 27]. Genetic engineering using the recombinant DNA technique provides a way to introduce DNA fragments in complex pathways and to regulate their expression. Many DNA-transfer technologies are available, including Agrobacterium-mediated [28, 29], microprojectile bombardment [29], direct DNA transfer to protoplasts, electroporation, micro-injection, macro-injection, impregnation by whiskers, impregnation by tissues, silicon carbide fibres, polyethylene glycol (PEG), floral dip, pollen tube pathway, ultrasonication and laser-mediated uptake. 
Presently, the three widely used methods are the Agrobacterium tumefaciens-mediated transfer (Figure 2), microprojectile bombardment (gene gun or biolistic method) (Figure 3) and direct gene transfer to protoplasts (Figure 4) $[15,30-33]$. These genetic transformation methods are categorized into indirect gene transfer, where foreign DNA is introduced by a plasmid and direct gene transfer, where physical and chemical processes are used, that is based on the penetration of the cellular wall $[32,34,35]$.

A

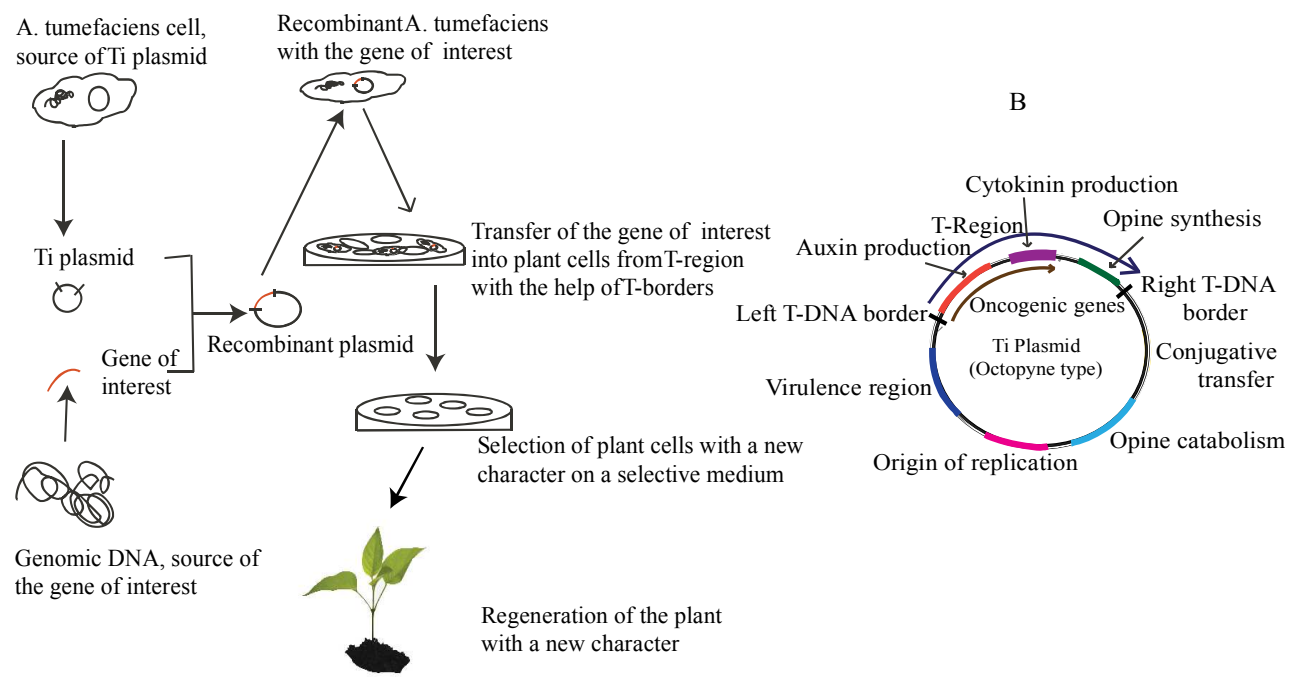

Figure 2. A. Creation of GM crop by Agrobacterium-mediated method. Ti plasmid is isolated from Agrobacterium tumefaciens and modified by using recombinant DNA technology, the T-region of the plasmid is replaced by the gene of interest but holding T-borders intact which plays a crucial role during the process of DNA transfer to the plant cell. The recombinant Ti-plasmid is transformed back to Agrobacterium tumefaciens, and then the recombinant strain is cultured with plant cells where the gene of interest is transferred from Agrobacterium tumefaciens into plant cells. B. Schematic representation of a Ti plasmid.

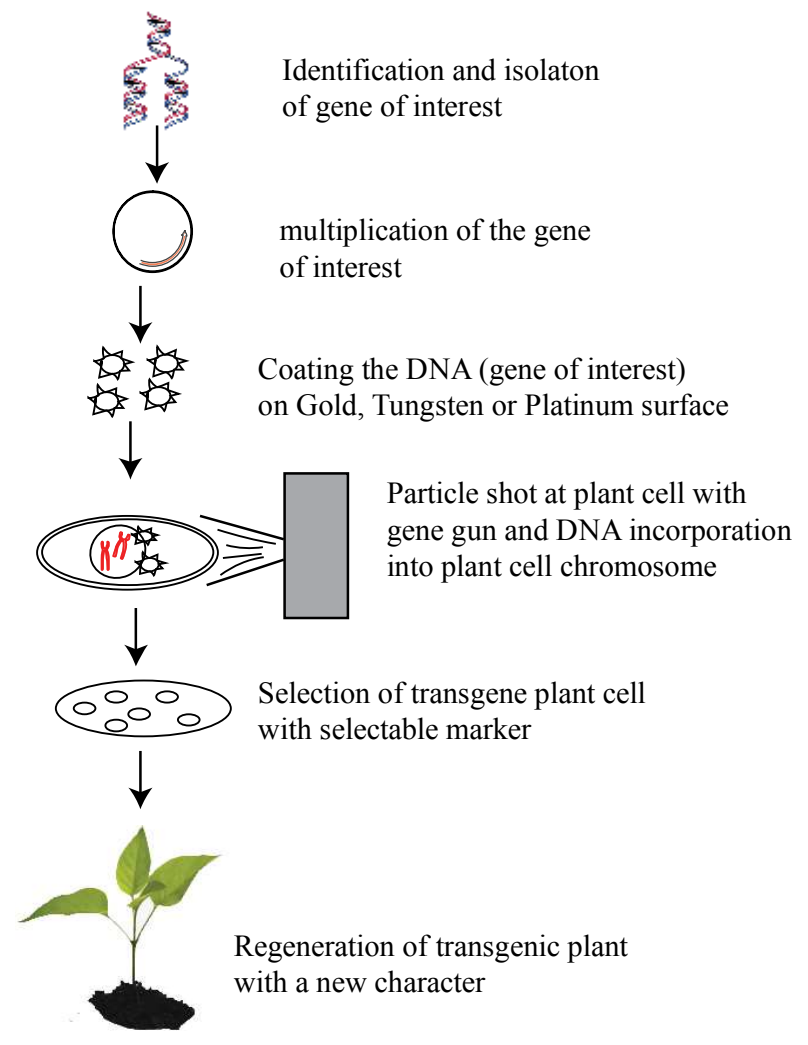

Source: Adapted from $[29,31,36]$

Figure 3. Creation of GM crop by particle bombardment method. The gene of interest is selected and amplified, then coated onto the surfaces of inert particles (micrometre-size gold, tungsten or platinum) by precipitation with calcium chloride and spermidine. The particles are accelerated such that they penetrate cells and tissues in a nonlethal manner. Once inside the cells, the DNA elutes off the particles and is expressed by the host cells, then a portion is stably incorporated into the host chromosomes. 


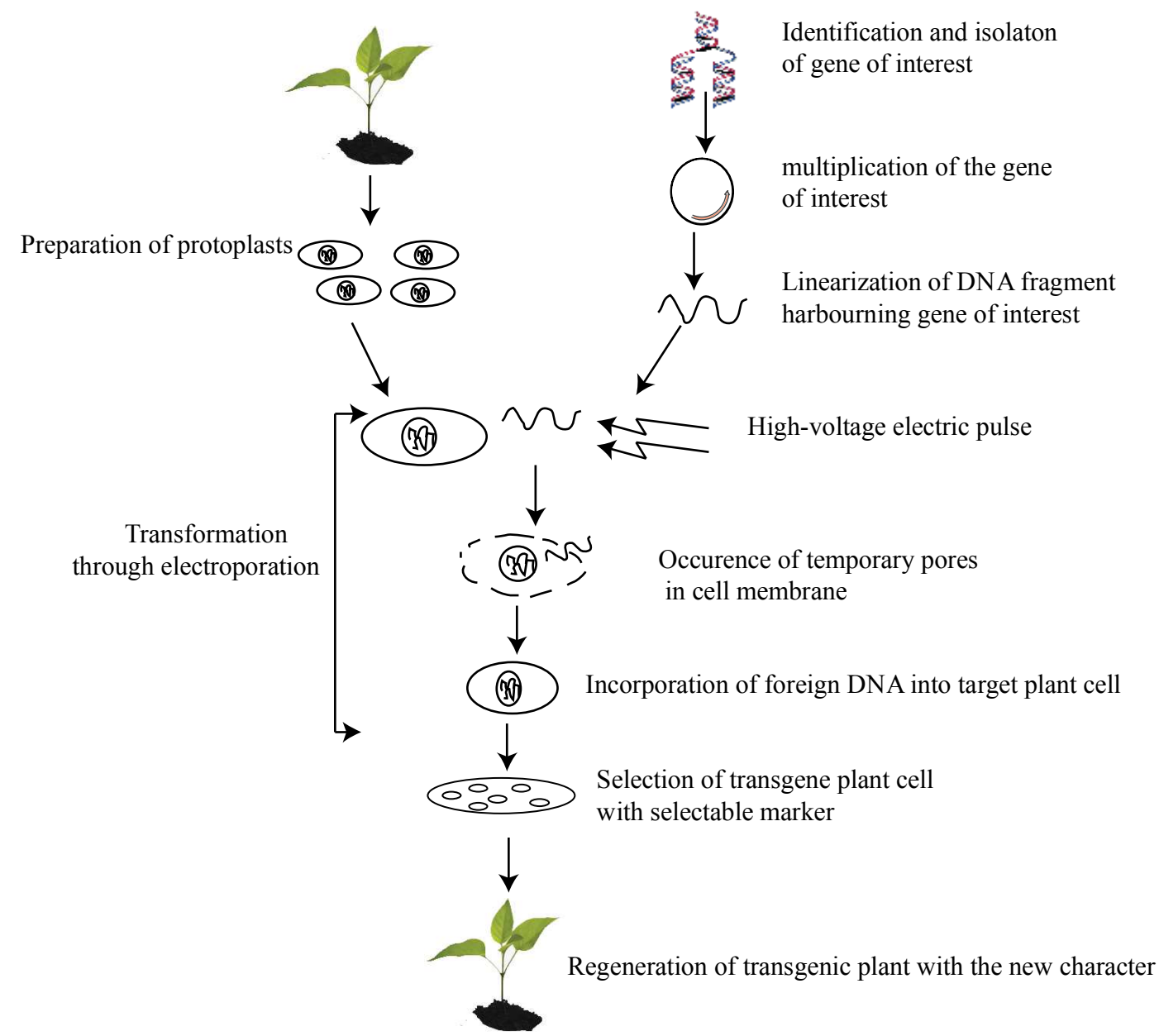

Source: Adapted from [36]

Figure 4. Plant regeneration from single protoplasts. Protoplast transfection involves protoplast isolation from plant tissue by enzymatic removal of the cell wall and subsequent transfer of plasmid DNA carrying genes of interest.

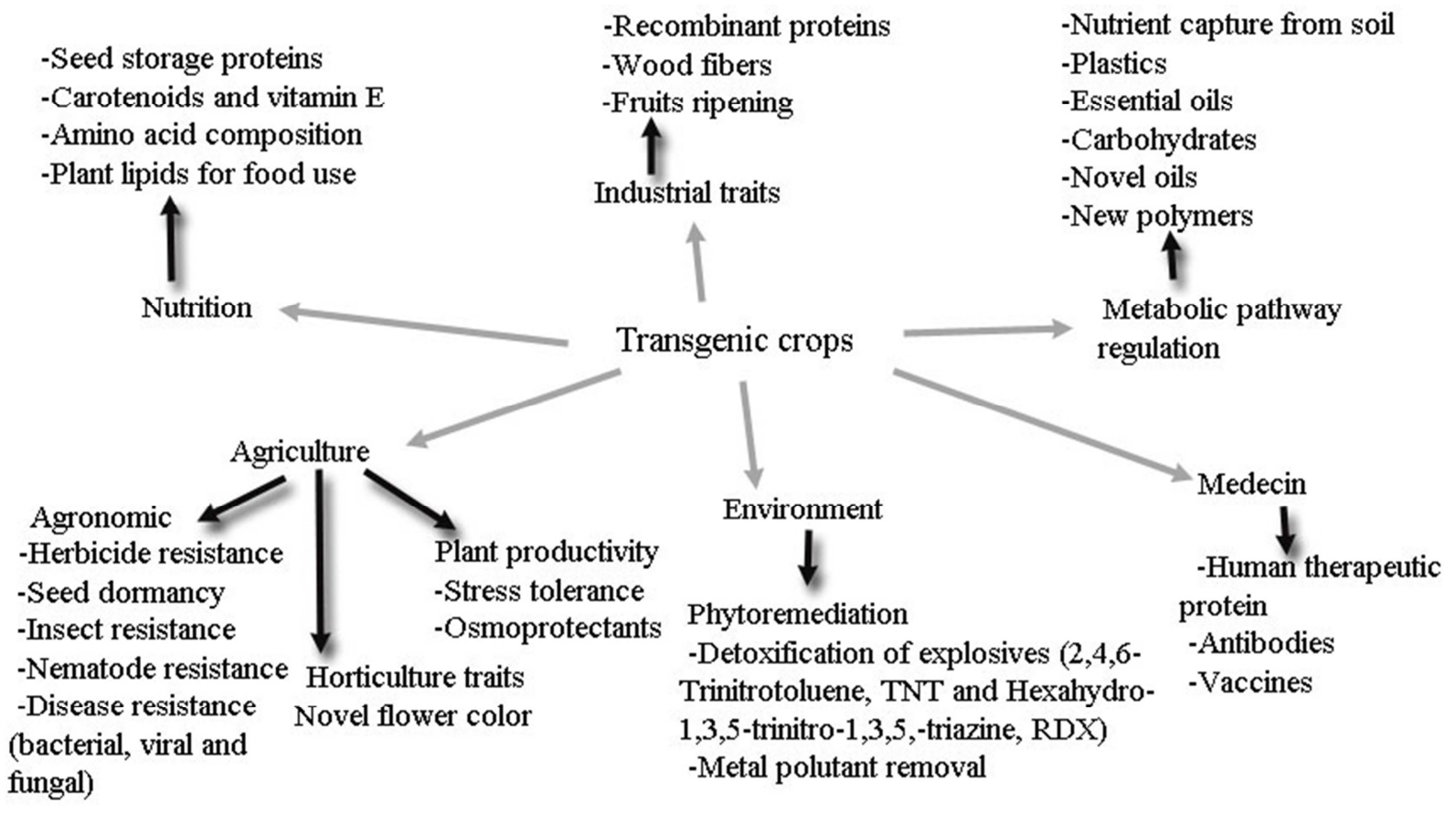

Source: Adapted from [31,37] 


\subsection{Applications of Transgenic Crops}

Various applications of transgenic crops have been envisaged and are under investigation for the future (Figure 5) $[31,37]$. The main transgene targets were pest resistance and herbicide tolerance, but also resistances to abiotic stress and improvement of the nutritional value were investigated. Furthermore, possible applications that are under development are the production of medically valuable proteins or chemicals in plants (pharma plants) e.g. transgene rice which can produce human serum albumin, or the production of edible plants containing vaccines, the production of bioplastics, phytoremediation, i.e. removal of metal pollutant $[31,38,39]$. Nowadays with climate change and global warming genetic engineering has been used to develop transgenic plants which are able to tolerate heat stress conditions [40].

\subsection{Detection of GM Crops, Products and Their Safety Issues}

Transgenic organisms have demonstrated several applications in different domain, especially in agriculture by improving quality and quantity of crops and reducing dependence to organic chemicals (herbicides and pesticides). However, possible impact of transgenic crops and food products to environment and public health have forced some government to establish food labeling regulations. According to the regulation EC 1830/2003 of European Council, when the amount of any authorized GM ingredient exceed $0.9 \%$ it must be indicated, while $0.5 \%$ is set as the threshold for nonauthorized GM [41]. However, The GM crops approved in one country do not certainly have the same approval status in another country. Thus numerous countries have executed labelling thresholds for unintended existence of approved GM crops well-defined as $0.9 \%$ in the EU and Russia, $3 \%$ in Korea, $5 \%$ in Japan, Indonesia, Thailand and Taiwan, and 1\% in Brazil [42]. The verification of GM content is based on either detecting the inserted genetic material at DNA level and the transcribed mRNA or identifying the subsequent recombinant protein, phenotype and metabolite. For this purpose, reliable screening methods have been developed for detection of unauthorized GM crops and labeling control. These include real-time polymerase chain reaction (RT-PCR) for detecting the inserted DNA, immunological assays for detecting the resulting protein (e.g. the enzyme-linked immunoassay (ELISA) and lateral flow sticks), or using different types of biosensors (electrochemical sensors, piezoelectric biosensors, surface plasmon resonance/optical biosensors) to detect the resulting phenotype (e.g. herbicide bioassays). These methods above can be coupled with other efficient emerging analytical technologies such as, chromatography, mass spectrometry and near infrared spectroscopy and DNA chip technology (microarrays) [4245]. So far only PCR has found broad application in GMO detection as a generally accepted method for regulatory purposes with the rapid, sensitive, specific and quantitative aspects $[44,46]$.

The evaluation of the safety of genetically engineered (GE) food and food ingredients is an absolute process of several steps. The U.S. Food and Drug Administration (FDA), 2013 and WHO, 2014 outlined that the GE plant developer must (a) identify the characteristics of the new genetic traits and analyzes the toxic and allergenic effects of the incoming food, (b) compare the nutrients levels in the new GE crop to traditional bred crops, that include fiber, protein, fat, vitamins, and minerals, (c) study the stability of introduced gene, (d) profile the nutritional effects connected with genetic modification and any unintended effects associated with gene insertion, (e) submit this information to national authorities for a safety assessment and compliance with the law $[47,48]$. WHO recommends the use of codex alimentarius guidelines [49].

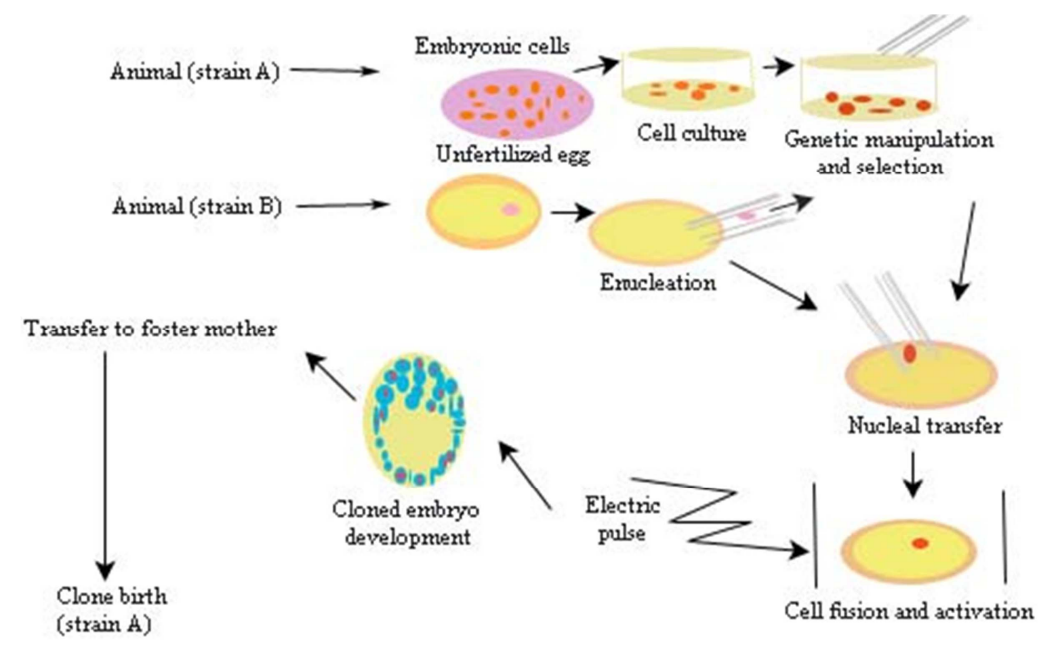

Source: $[55,56]$

Figure 6. Schematic diagram of the somatic cloning process. Cells are collected from donor (Strain A) and cultured in vitro. A matured oocyte (from Strain B) is then enucleated and a donor cell is transferred into the enucleated oocyte. The somatic cell and the oocyte are then fused and the embryos is allowed to develop to a blastocyst in vitro. The blastocyst can then be transferred to a foster mother and cloned animals are born after completion of gestation. 


\section{Transgenic Animals}

A transgenic animal is an animal that both carries a specific gene from a different species or results from genomic DNA manipulations and undergoes deliberate modification of its genome. Recombinant DNA technology is used to create a transgenic animal by introducing a foreign DNA into the animal's genome. The constructed recombinant DNA should to be stably maintained, expressed and inherited and passed on to subsequent generations. The most important thing is that the heritability of the genetic modification can be achieved by creating an animal that carries the modification in the genome of its germ line: all offspring derived from this animal will be completely transgenic, as they will carry this modification in all their somatic and germ line cells [31, 50].

The establishment of a stable transgenic animal implies that the foreign DNA is present in gametes or one-cell embryos to allow its transmission to progeny. Depending on the animal species, the gene of interest can be transferred using different methods such as DNA microinjection, spermmediated DNA transfer, viral-vector mediated DNA transfer, gene transfer using embryonic cells and somatic cell nuclear transfer (Figure 6) [51-54].

\section{Applications for Transgenic Animals}

The production of transgenic organisms has been a major technological advance in the study of biology. Transgenic animals have provided new perceptions into the study of the mechanisms of gene regulation and developmental biology. Subsequently, this technology has allowed significant advances in other branches of biomedical sciences including a) the implication of some genes in the development cancer (oncogenes) and oncogenic viruses; b) the mechanisms of regulation and cell interaction in the immune system; c) models for human genetic diseases; d) the mechanisms and control of growth; e) production of biopharmaceuticals, myelin basic proteins from mice, monoclonal antibodies from goats, vaccines and insulin from chicken and eggs, human hemoglobin from pigs, protein $\mathrm{C}$ from cow, human erythropoietin from rabbit, human factors VII and IX from sheep and other compounds and f) the basic mechanisms of biology and genetics [31, 54, 57].

Furthermore, transgenic technology is used in production of dragline silk (BioSteel). BioSteel is one of the spiders silk which is a protein fiber spun by spider. BioSteel is known to possess outstanding physical and mechanical properties, toughness, elasticity, strength and is weight by weight five times stronger than steel and three times stronger than Kevlar and absolutely biodegradable and biocompatible; these properties are exploited to make medical devices like surgical fiber from BioSteel. Nowadays transgenic goat duly can produce dragline silk in milk as water-soluble silk proteins [58-61]. Transgenic technology is also employed to generate a novel variety of ornamental fish, transgenic zebrafish, which exhibits vital applications in various domain including biomedicine. Transgenic zebrafish is used as a genetic model to comprehend the human tissue regeneration defects and encourage the progress of regeneration medicine, where zebrafish helps in developing infection disease model (e.g. tuberculosis), screening chemical genetic, emerging cancer pathogenesis model (e.g. melanoma, leukemia), understanding toxicological process (e.g. copper homeostasis). Zebrafish is transparent and under a suitable organ/tissue specific promoter, it can express fluorescent proteins which helps in visualizing the phenotype of the organ [62-66].

There are various potential applications of transgenic technology to develop new or altered strains of agriculturally important livestock. Practical applications of transgenesis in livestock production include improving the desirable traits such as high milk production and composition, improved meat production, rapid growth rate, feed usage, carcass composition, resistance to diseases, enhanced reproductive performance and prolificacy $[57,67]$.

\section{Conclusion}

Genetic modification provides a beneficial way of modifying the genome of both crops and animals to improve their production and composition with benefits to the environment, farmers and consumers. To establish a stable transgenic organism (or a Genetically Modified Organism), the genome modification can be performed employing specific methods according to organism species, then such a technique leads to creation of a new organism previously not found in nature. Nowadays more than 18 million farmers from different countries that include USA, Canada, Argentine, Mexico and China, are interested in transgenic crop varieties as an alternative to feed a hungry world. Transgenic animals showed diverse application in different domain such as the use of BioSteel in medicine. To avoid concerns regarding genetically modified crops, food and food ingredients, a competent method based either on DNA or protein must be used to monitor and verify the presence and the amount of GM varieties of crops and food products. A competent biotechnological team could then assess the safety of GM food before being released on the market.

\section{Acknowledgements}

Authors sincerely acknowledge the valuable support provided by the National Natural Science Foundation of China (No. 31401638), the Natural Science Foundation of Jiangsu Province (BK20130132), and the 111 Project (111-2-06).

\section{References}

[1] Yashveer S, Singh V, Kaswan V, Kaushik A, Tokas J (2014) Green biotechnology, nanotechnology and bio-fortification: perspectives on novel environment-friendly crop improvement strategies. Biotechnol Genet Eng Rev 30: 113-26 
[2] Brookes G, Barfoot P (2015) Global income and production impacts of using GM crop technology 1996-2013. GM Crops \& Food 6: 13-46

[3] Hao B, Xue Q, Marek TH, Jessup KE, Hou X, Xu W, Bynum ED, Bean BW (2015) Soil water extraction, water use, and grain yield by drought-tolerant maize on the Texas High Plains, Agricultural Water Management 155: 11-21

[4] Gartland KM, Gartland JS (2016) Green Biotechnology for Food Security in Climate Change, In: Reference Module in Food Science. Elsevier Inc

[5] Palmgren MG, Edenbrandt AK, Vedel SE, Andersen MM, Landes X, Osterberg JT, Falhof J, Olsen LI, Christensen SB, Sandoe P, Gamborg C, Kappel K, Thorsen BJ, Pagh P (2015) Are we ready for back-to-nature crop breeding?. Trends Plant Sci 20: $155-164$

[6] Wieczorek A (2003) Use of biotechnology in agriculturebenefits and risks. Biotechnology 3: 1-6

[7] Maghari BM, Ardekani AM (2011) Genetically Modified Foods and Social Concerns. Avicenna J Med Biotech 3: 109117

[8] Pattron DD (2005) A survey of genetically modified foods consumed, health implications and recommendations for public health food safety in trinidad. Internet Journal of Food Safety 5: 4-14

[9] Nielsen CP, Thierfelder K, Robinson S (2003) Consumer preferences and trade in genetically modified foods. J Policy M 25: 777-794

[10] Kim YG, Jang SY, Kim AK (2014) Application of the theory of planned behavior to genetically modified foods: Moderating effects of food technology neophobia. Food Res Int 62: 947-954

[11] Afidchao MM, Musters CJM, Wossink A, Balderama OF, de Snoo GR (2014) Analysing the farm level economic impact of GM corn in the Philippines. NJAS-Wagen J Life Sc 70-71: 113-121

[12] Sanglestsawai S, Rejesus RM, Yorobe JM (2014) Do lower yielding farmers benefit from Bt corn? Evidence from instrumental variable quantile regressions. Food Policy 44: 285-296

[13] Takabatake R, Onishi M, Futo S, Minegishi Y, Noguchi A, Nakamura K, Kondo K, Teshima R, Mano J, Kitta K (2015) Comparison of the specificity, stability, and PCR efficiency of six rice endogenous sequences for detection analyses of genetically modified rice. Food Control 50: 949-955

[14] James C (2013) Global status of commercialized biotech/gm crops: 2013. ISAAA Brief 46. ISAAA, Ithaca, NY

[15] Ye X-G (2015) Development and application of plant transformation techniques. J Integr Agr 14: 411-413

[16] Dawson TP, Perryman AH, Osborne TM (2014) Modelling impacts of climate change on global food security. Climatic Change

[17] Hough G, Sosa M (2015) Food choice in low income populations - a review. Food Qual Prefer 40: 334-342

[18] Chaumet JM, Ghersi G, Rastoin JL (2014) Food consumption in 2050. In: Agrimonde - scenarios and challenges for feeding the world in 2050, Sandrine P, Sébastien T, Dorin B (Eds.)
Éditions Quæ, RD 10, 78026 Versailles Cedex, France: pp: $59-72$

[19] Grafton RQ, Williams J, Jiang Q (2015) Food and water gaps to 2050: Preliminary results from the global food and water system (gfws) platform. Food Sec

[20] McGloughlin MN (2012) Prospects for increased food production and poverty alleviation. University of California Systemwide Biotechnology Research and Education Program (UCBREP), University of California Davis, California: pp: $551-561$

[21] Wu WB, Yu QY, Peter VH, You LZ, Yang P, Tang HJ (2014) How could agricultural land systems contribute to raise food production under global change? J Integr Agr 13: 1432-1442

[22] Vemireddy LR (2014) Food and nutrition security: Biotechnology intervention. Springer Science Reviews 2: 3549

[23] Huang J, Rozelle S, Pray C, Wang I (2002) Plant biotechnology in China. Science 295: 673-677

[24] James C (2011) Global status of commercialized biotech/GM crops: 2011. ISAAA brief no.43. ISAAA: Ithaca, NY.

[25] Guo M, Bian X, Wu X, Wu M (2011) Agrobacteriummediated genetic transformation: History and progress. PMA (Ed.) InTech

[26] Newell CA (2000) Plant transformation technology: Developments and applications. Mol Biotechnol 16: 53-65

[27] Svab Z, Hajdukiewicz P, Maliga P (1990) Stable transformation of plastids in higher plants (antibiotic resistance/maternal inheritance/projectile transformation/rna genes). Proc Natl Acad Sci USA 87: 8526-8530

[28] Baskar V, Gangadhar BH, Park SW, Nile SH (2016) A simple and efficient Agrobacterium tumefaciens-mediated plant transformation of Brassica rapa ssp. pekinensis. 3 Biotech 6: $1-6$

[29] Rashid AHA, Lateef DD (2016) Novel Techniques for Gene Delivery into Plants and Its Applications for Disease Resistance in Crops. Am J Plant Sci 07: 181-193

[30] Shewry PR, Jones HD, Halford NG (2008) Plant biotechnology: Transgenic crops. Adv Biochem Engin/Biotechnol 111: 149-186

[31] Brandenberg O, Dhlamini Z, Sensi A, Ghosh K, Sonnino A (2011) Introduction to molecular biology and genetic engineering. Food and Agriculture Organization of the United Nations, Rome, Module A

[32] Rivera AL, Gómez-Lim M, Fernández F, Loske AM (2012) Physical methods for genetic plant transformation. Phys Life Rev 9: 308-345

[33] He Y, Wang Q, Zeng J, Sun T, Yang G-X, He G-Y (2015) Current status and trends of wheat genetic transformation studies in china. J Integr Agr 14: 438-452

[34] Bajwa KS, Shahid AA, Rao AQ, kiani MS, Ashraf MA, Dahab AA, Bakhsh A, Latif A, Khan MAU, Puspito AN, Aftab A, Bashir A, Husnain T (2013) Expression of calotropis procera expansin gene cpexpa3 enhances cotton fibre strength. Aust J Crop Sci 7: 206-212 
[35] Kohli A, Leech M, Vain P, Laurie DA, Christou P (1998) Transgene organization in rice engineered through direct DNA transfer supports a two-phase integration mechanism mediated by the establishment of integration hot spots. Proc Natl Acad Sci USA 95: 7203-7208

[36] Narusaka Y, Narusaka M, Yamasaki S, Iwabuchi M (2012) Methods to Transfer Foreign Genes to Plants, in: Transgenic Plants - Advances and Limitations, PhD. Yelda Ozden Çiftçi (Ed.) InTech.

[37] Rylott EL, Budarina MV, Barker A, Lorenz A, Strand SE, Bruce NC (2011) Engineering plants for the phytoremediation of RDX in the presence of the co-contaminating explosive TNT. New Phytol 192: 405-413

[38] Shelton AM (2007) Considerations on the use of transgenic crops for insect control. J Dev Stud 43: 890-900

[39] Qi X, Chen S, Sheng Y, Guo M, Liu Y, He X, Huang K, Xu W (2015) Safety assessment of genetically modified rice expressing human serum albumin from urine metabonomics and fecal bacterial profile. Food Chem Toxicol 76: 1-10

[40] Lavania D, Dhingra A, Siddiqui MH, Al-Whaibi MH, Grover A (2015) Current status of the production of high temperature tolerant transgenic crops for cultivation in warmer climates. Plant physiology and biochemistry: PPB / Societe francaise de physiologie vegetale $86: 100-108$

[41] Manzanares-Palenzuela CL, Martín-Fernández B, SánchezPaniagua LM, López-Ruiz B (2015) Electrochemical genosensors as innovative tools for detection of genetically modified organisms. Trends Analyt Chem 66: 19-31

[42] Randhawa G, Singh M, Sood P (2016) DNA-based methods for detection of genetically modified events in food and supply chain. Current Science 110: 1000-1009

[43] Kamle S, Ali S (2013) Genetically modified crops: Detection strategies and biosafety issues. Gene 522: 123-132

[44] Tripathi L (2005) Techniques for detecting genetically modified crops and products. Afr J Biotechnol 4: 1472-1479

[45] Lin CH, Pan TM (2016) Perspectives on genetically modified crops and food detection. J Food Drug Anal 24: 1-8

[46] Ballari RV, Martin A, Gowda LR (2013) Detection and identification of genetically modified EE-1 brinjal (Solanum melongena) by single, multiplex and SYBR(R) real-time PCR. J Sci Food Agric 93: 340-347

[47] WHO (2014) Frequently asked questions on genetically modified foods

[48] U.S. Department of Health \& Human Services, U.S. Food and Drug Administration (2013) FDA facts: Food from genetically engineered plants

[49] Codex Alimentarius Commission (2011) Principles for the risk analysis of foods derived from modern biotechnology

[50] Rajoriya R, Rajoriya S, Kumar N (2013) Transgenic animals: Prospects for improving livestock productivity. J Bio Innov 2: 240-259

[51] Houdebine LM (2002) The methods to generate transgenic animals and to control transgene expression. J Biotechnol 98: $145-160$
[52] Dunn DA, Pinkert CA, Kooyman DL (2005) Foundation review: Transgenic animals and their impact on the drug discovery industry. Drug Discovery Today 10: 757-767

[53] Robl JM, Wang Z, Kasinathan P, Kuroiwa Y (2007) Transgenic animal production and animal biotechnology. Theriogenology 67: 127-133

[54] TR B, RR K, MS B, SY M (2013) Transgenic animals and their application in medicine. Int J Med Res Health Sci 2: 107116

[55] Tian XC, Kubota C, Enright B, Yang X (2003) Cloning animals by somatic cell nuclear transfer - biological factors, Reprod Biol Endocrinoly 1

[56] Ogura A, Inoue K, Wakayama T (2013) Recent advancements in cloning by somatic cell nuclear transfer, Philos Trans R Soc Lond B Biol Sci 368: 2011.0329

[57] Wheeler MB, Walters EM (2001) Transgenic technology and applications in swine. Theriogenology 56: 1345-1369

[58] Lee BH (2014) Plant biotechnology, animal biotechnology, and safety assesment. In: Fundamentals of food biotechnology. Wiley: pp: 520 pages in press

[59] An B, Tang-Schomer MD, Huang W, He J, Jones JA, Lewis RV, Kaplan DL (2015) Physical and biological regulation of neuron regenerative growth and network formation on recombinant dragline silks. Biomaterials 48: 137-146

[60] Chung H, Kim TY, Lee SY (2012) Recent advances in production of recombinant spider silk proteins. Curr Opin Biotechnol 23: 957-964

[61] Tokareva O, Michalczechen-Lacerda VA, Rech EL, Kaplan DL (2013) Recombinant DNA production of spider silk proteins. Microb Biotechnol 6: 651-663

[62] Carvalho R, Sonneville Jd, Stockhammer OW, Savage NDL, Veneman WJ, Ottenhoff THM, Dirks RP, Meijer AH, Spaink HP (2011) A high-throughput screen for tuberculosis progression. PLoS One, 6: e16779

[63] Herna'ndez PP, Allende ML (2008) Zebrafish (Danio rerio) as a model for studying the genetic basis of copper toxicity, deficiency, and metabolism. Am J Clin Nutr 88: 835S-839S

[64] Kaufman CK, White RM, Zon L (2009) Chemical genetic screening in the zebrafish embryo. Nat Protoc 4: 1422-1432

[65] White RM, Cech J, Ratanasirintrawoot S, Lin CY, Rahl PB, Burke CJ, Langdon E, Tomlinson ML, Mosher J, Kaufman C, Chen F, Long HK, Kramer M, Datta S, Neuberg D, Granter S, Young RA, Morrison S, Wheeler GN, Zon LI (2011) Dhodh modulates transcriptional elongation in the neural crest and melanoma. Nature 471: 518-522

[66] Zhang B, Shimada Y, Kuroyanagi J, Umemoto N, Nishimura Y, Tanaka T (2014) Quantitative phenotyping-based in vivo chemical screening in a zebrafish model of leukemia stem cell xenotransplantation. PLoS One 9: e85439

[67] Wheeler MB (2007) Agricultural applications for transgenic livestock. Trends Biotechnol 25: 204-210 